were in the field of heat radiation. He invented a differential thermometer, and 'Leslie's Cube' appears in every school physics textbook. He wrote a number of papers and books including Experimental Inquiry into the Nature and Properties of Heat and Radiation of Heat and also published on geometry, analysis and trigonometry. In 1805, Playfair resigned his chair of mathematies in Leslie's favour, and in 1819, Leslie became profossor of natural philosophy at Edinburgh. Leslie was a first-class experimentalist and designer of apparatus, but a poor lecturer. He travelled widely and took a considerable interest in European, especially French, science. He died on November 3,1832 .

\section{Science and Parliament}

Under the title Science and Parliament, the Organiza. tion for Economic Co-operation and Development has publishod an admirable final report, presented by $P$. Piganiol, on the Second Parliamentary and Scientific Conference, organized jointly with the Council of Europe, at Vienna, during May 23-27, 1965 (Pp. 177. Paris: Organization for Economic Co-operation and Development; London: H.M.S.O., 1965. 8 franes; $12 s .6 d$.; 2 dollars). Besides M. Piganiol's report on the debates and the formal conclusions of the Conferonce, it includes the text of the five addresses, of which those of Prof. G. Hess, Mr. K. Lindsay, Mr. Quintin Hogg and Mr. G. Palewski are outstanding. Annexes include a list of participants, the programme and the recommendations and resolutions for following up the Conference. The recommendations direct attention to the conclusion that there should be in each country a Minister charged solely, or together with other responsibilities, with the promotion and co-ordination of science policy in all its aspects. They invite the national Parliaments to set up, without delay, parliamentary and scientific committees where they do not exist; to examine, where the need arises, the advisability of ehanging their procedure and the organization of their work by setting up standing parliamentary committees for science; and to strengthen the machinery for informing their members about scientific questions. The first resolution is concerned with the development of European co-operation in the scientific field and advocates the organization of a general debate on the activities of international and European organizations in this field and their more effective co-ordination. The second suggests a study programme to follow up the Parliamentary and Scientific Conference. Prof. G. Hess's opening address dealt with "Science and Society"; Mr. K. Lindsay's survey, "Science and Parliament", included brief accounts of scientific policy in Franco, Belgium, Westorn Germany and the United Kingdom. Mr. Hogg discussed spocifie present and foreseeable impacts of science on political life; Mr. G. Palewski "A Scientific Research Policy in the World of Today"; and Mr. K. Czernetz described the common tasks of parliamentarians and scientists in drawing up a science policy.

\section{Experimental Cartography}

The Natural Environment Research Council has awarded a grant of $£ 11,035$ to $\mathrm{Mr}$. D. P. Bickmore, director of the Cartographic Department of the Clarendon Press, for a detailed survey of the needs and problems of the various users of cartographic mothods and of the techniques being developed in Britain and overseas. Mr. Bickmore is a senior Research Fellow of the Royal College of Art. The survey, which will last 18 months, will be in two main parts; the first will be concerned with appraising needs, problens and present techniques, and the second with proposing the direction of further work. Besides the information traditionally converted into maps, the study will also be concerned with other information that could usefully be mapped; this includes oceanographic surveys, surface water records and information from satellites to archaeological surveys, population and health censuses and traffic planning probably using animated cartography. The survey will also be concorned to keep abroast of the flow of new information over the range of physical and social sciences. This will involve the application of automatic data processing techniques to eartography. A programme of experiments on the perceptual processes of map reading will be undertaken to assess the most efficient presentation of information. Animated maps showing changes with time will be necessary to aid, for example, planning and traffic studies.

\section{Building Social Institutions}

Dr. H. V. Perlmutter's essay, Towards a 'Theory and Practice of Social Architecture: the Building of Indis. pensable Institutions, is based on his experience at the Centro for International Studies at the Massachusetts Institute of Technology, at the Division of Industrial Mental Health of the Menninger Foundation, Yale University School of Industrial Administration, at the Institut pour l'Etude des Méthodes de Direction de l'Entreprise, and as consultant to some world orgarizations (Tavistock Pamphlet No. 12. Pp. vii +60. London: Tavistock Publications, 1965. 12s. 6d.). It is in three parts: the first outlines the need for a theory and practice of social architecture, starting from the assumption that men need to understand not only how to change the attitudes of individuals in desirable directions but also how to create social institutions which guarantee valued actions to meet the indispensable needs of socicty. It is also assumed that the measure and locus of enduring social progress and human welfare depend on the viability of indispensable social institutions. Such institutions, Dr. Perlmutter thinks, are themselves better understood and more easily created if increasing attention is given to the interdependence of the theory and practice of institutionbuilding. The social part outlines the essential steps to be taken towards a theory of social architecture, including the conceptual requirements and the integration of the various dimensions involved. The third part is conecrned with the actual practice of social architecture and describes the collaborative relation between the social architects, or persons trained in the applied behavioural sciences, and their clients, the actual institution-builders. The essay defines an area of study in which the theories and practices of building institutions could receive direct and concentrated consideration both by research workers and prac. titioners. In conclusion, Dr. Perlmutter defines social architecture as involving the development of concepts leading to research which guides men to create institutions that embody positive values and remain responsive to the needs of individuals within and without the institution, and the practical building of such institutions. In the contemporary situation, more than ever before, the hopo for eivilization lies in improving man's talent to create institutions which guarantee peace and security and promote economic and social development.

\section{Organo-mineral Complex in Soils}

For a full appreciation of the mechanism of the formation of complexes of clay and organic matter, a better knowledge of the structure and composition of the organic matter is required. The properties of this matter may, however, vary with soil or extraction technique. A further well-documented review of the present position, entitled "Interaction between Clays and Organic Compounds in Soils". Part 2: "Adsorption of Soil Organic Compounds and its Effect on Soil Properties", by D. J. Greenland, is presented in Soils and Fertilizers (28, 521; 1965). The humic acid fraction is composed of polymers of amino-acids and phenolic compounds. These are mainly of molecular weight $20,000-50,000$, roughly spherical and relatively rigid, and give aqueous solutions of low viscosity. The fulvic acids are mainly phenolic sub- 